\section{High-temperature wear-resistant materials based on silicon nitride}

Natalia I. ERShOVA - Federal State Unitary Enterprise, Obninsk Research and Production Enterprise, Technologiya - patent@technologiya.ru

IRINA YU. KELINA - Federal State Unitary Enterprise, Obninsk Research and Production Enterprise, Technologiya - kelinai@technologiya.ru

Rolling bearing is one of the most demanding assembly units and in many respects defines operational behavior of current aerospace engineering, oil and gas transfer facilities, output turbines, heat- and electrogenerating sets, nuclear reactor turbines, land and water transport, pump blocks. Ceramic materials based on silicon nitride exhibit high hardness and wear resistance and still have less density as compared with metals, which makes it possible to attain service life at high temperatures and at high revolutions ( 100 thousands rpm and more), in corrosion environment, and where long service life, low noisiness and high positional accuracy are required. Hot-pressed silicon nitride possesses maximum strength in relation to other ceramic materials, which is why it appears to be particularly promising for use in rolling bearings. A wide range of ceramic materials based on silicon nitride has been developed. Hotpressed materials OTM-906 and OTM-914 correspond in composition, structure and properties to the best in the world analogues of bearing ceramic materials of NC-101C and NBD-200 grades. A composite material in $\mathrm{Si}_{3} \mathrm{~N}_{4}-\mathrm{BN}$ system has been developed. The lack of chemical interaction between silicon nitride and boron nitride having fine self-lubricating properties determines the possibility for the development of bearing retaining rings with selective boron nitride distribution for the enhancement of self-lubrication effect. The results of an investigation into tribological behavior of the developed materials and the results of the ceramic rolling bearings testing are presented.

Keywords: silicon nitride, boron nitride, hot pressing, rolling bearing, bearing cage, wear resistance, back-to-back endurance

\section{Introduction}

Rolling bearing is one of the most demanding assembly units and in many respects defines the operational behavior of current aerospace engineering, oil and gas transfer facilities, output turbines, heat- and electrogenerating sets, nuclear reactor turbines, land and water transport, pump blocks.

To solve new problems in bearings structures, silicon nitride is most often used. This ceramic material offers high hardness, wear and strain resistance at high temperatures, and less density as compared to steel, as an example.

Research into tribological behavior, an investigation of the effects of various factors on friction and wear of the materials are currently central and make it possible to expand the fields of their application in wear-resistant articles.

\section{Requirements for ceramic materials}

The following requirements are placed on the materials for bearing components:

Bearing race: hardness - no less than $59 \mathrm{HRC}$ at $20-1000^{\circ} \mathrm{C}$; $100 \%$ density; change in dimensions on holding at operating temperatures for $1500 \mathrm{hrs}$ - no more than $0,15 \%$; lack of adhesion in friction pair in the air and in vacuum; vibration resistance; possibility of machining and finishing to high surface finish class.

Rolling elements: friction coefficient - no more than 0,1; load of failure - no less than 850 000, 1200000 and $3200000 \mathrm{~N}$ for balls $12,7,15,8$ and $25,4 \mathrm{~mm}$ in diameter respectively; heat resistance - no less than $1000^{\circ} \mathrm{C}$; ultimate bending strength 600-650 MPa; back-to-back endurance - no less than those for bearing steel - 346 million cycles.
Dr. Natalia I. Ershova graduated from Moscow Steel and Alloys Institute, Physical and Chemical department, then worked as an engineer at FSUE ORPE "Technologiya" in the laboratory for the development of $\mathrm{Si}_{3} \mathrm{~N}_{4}$ - and $\mathrm{SiC}$-based ceramic materials. In 2004 graduated from Russian State Institute for the Intellectual Property. In 2006 she successfully completed her dissertation work on $\mathrm{Si}_{3} \mathrm{~N}_{4}-\mathrm{BN}$ ceramics for high-temperature application and got a PhD degree at the Institute for Physical and Chemical Problems of Ceramic Materials of the Russian Academy of Sciences. Her research work is represented in 16 articles, 4 patents, proceedings of many international and Russian conferences. At present time she is the head of Patent and Information Department at FSUE ORPE "Technologiya". Her scientific activities is connected with the search for the new scientific-engineering decisions in ceramic, composite and glass materials technologies, evaluation of scientific and engineering level of FSUE ORPE "Technologiya" projects.

Dr. Irina Yu. Kelina graduated from the Mendeleev Moscow Chemical-Technological Institute. She has got a $\mathrm{PhD}$ scientific degree and then worked at FSUE ORPE "Technologiya" in the laboratory for the development of $\mathrm{Si}_{3} \mathrm{~N}_{4}$ - and $\mathrm{SiC}$-based ceramic materials as an engineer and as a head of section. Now she is a laboratory head and senior research associate at FSUE ORPE "Technologiya".

She is engaged in research and development activities on high-temperature monolithic and composite materials based on silicon nitride, with predetermined microstructure and controlled properties, and in hot-pressing technology for the manufacture of structural articles (thermal-, wear- and shock-resistant articles for use in purpose-built equipment and advanced gas-turbine engines). The main results of her research work are represented in 50 papers, including articles, patents and proceedings of Russian and international conferences.

Bearing cage: heat resistance - no less than $1000^{\circ} \mathrm{C}$; ultimate bending strength - no less than $35 \mathrm{MPa}$; static modulus of elasticity - 70-100 GPa; wear resistance; machinability [1].

\section{Experimental}

In this work the $\mathrm{Si}_{3} \mathrm{~N}_{4}$-based materials manufactured by hotpressing technique of OTM-906 and OTM-914 grades (yttria as a sintering aid), OTM-917 (magnesia as a sintering aid) and OTM-918 (composite material in $\mathrm{Si}_{3} \mathrm{~N}_{4}-\mathrm{BN}$ system) have been investigated.

Back-to-back endurance testing for determination of serviceability at variable loads was carried out at joint stock company VNIPP on the 9- position testing machine LTM 01-00-00 with the use of specimens-discs (balls contact with flat surface) in the assembly unit patterned after axial bearing 8100 with one flat bearing race. Path speed for the hot-working steel balls 4,7 $\mathrm{mm}$ in diameter measured $100 \mathrm{rpm}$, corresponding to $0,5 \times 10^{6}$ touchdowns per hour. As a lubricant, industrial oil I20 was used. The testing was carried out at room temperature and at maximum strains $\left(\sigma_{\text {мах }}\right)$ equal to $35000 \mathrm{MPa}$ and $45000 \mathrm{MPa}$. Calculation of loads required to produce the specified strains was carried out by the following formula: $\sigma_{\text {мах }}=6568{ }^{3} \sqrt{ } \mathrm{H} / r^{2}$, where $\mathrm{H}$ is the loads, and $\mathrm{r}-$ the radius of contacting balls. 
Wear resistance testing was carried out with the use of balls $9,5 \mathrm{~mm}$ in diameter manufactured from bearing steels, metalceramics MK307 and hot-pressed silicon nitride produced in Germany. Ball-on-disk sliding speed in the absence of lubrication at a load of $30 \mathrm{~N}$ measured $500 \mathrm{rpm}$.

Materials heat resistance was assessed in the temperature range of $600-900{ }^{\circ} \mathrm{C}$ for $5-250 \mathrm{hr}$.

Tribological testings were carried out on the friction test machine SRV («Optimol» company) for the purpose of antiwear and antiseizure characteristics evaluation with the use of the OTM-906, OTM-914, OTM-914 ceramic samples in comparison with the steel samples properties and with the use of standard engine oils: mineral oil M-16IHP-3 and synthetic oils M-8V S B-3V.

Friction coefficient evaluation was carried out on the friction test machine SMC-2 with the use of friction pairs disc-on-disc and compound oil lubricant.

\section{Results and discussion}

As a result of testing, it has been found that back-to-back endurance of the OTM-906, OTM-914 and OTM-917 samples is reasonably high and with the 50\% damage probability measures to about 180 million cycles and 127-682 hr (Table 1). Spread in service life values is determined by surface condition as well as crystalline and amorphous phases uniformity. Backto-back endurance of the samples from hot-working steel and stainless steel measures 134 and 326 million cycles.

\begin{tabular}{|c|c|c|c|c|}
\hline \multirow[t]{2}{*}{ Material } & \multirow[t]{2}{*}{$\begin{array}{c}\text { Maximum } \\
\text { strain } \\
\text { [MPa] }\end{array}$} & \multirow[t]{2}{*}{$\begin{array}{l}\text { Duration of } \\
\text { testing [hr] }\end{array}$} & \multicolumn{2}{|c|}{$\begin{array}{l}\text { Back-to-back } \\
\text { endurance [million } \\
\text { cycles] under damage } \\
\text { probability equal to }\end{array}$} \\
\hline & & & $10 \%$ & $50 \%$ \\
\hline $\begin{array}{l}\text { OTM-906, } \\
\text { OTM-914 }\end{array}$ & $3500-4500$ & $127-500$ & 31,0 & 155 \\
\hline OTM-917 & 3500 & $160-190$ & 25,2 & 176 \\
\hline HPSN, Japan & - & - & 30,0 & \\
\hline SN-101C [2] & $\begin{array}{r}5900 \\
(9,525 \mathrm{~mm} *) \\
\end{array}$ & $>400$ & - & - \\
\hline & 4800 & & - & $>72$ \\
\hline & 6900 & & - & $>30$ \\
\hline SN-101 [2] & 2900-3700 & $500-1000$ & & - \\
\hline
\end{tabular}

* Balls diameter

Table 1. Results of the ceramic materials back-to-back endurance testing

1. táblázat Kerámia anyagok egymáson való súrlódási vizsgálatának eredményei

An important point is that failure development proceeds slowly and fatigue defect class is similar to that for steels - local pitting, in distinction to the catastrophic failure that is often observed with hot-pressed silicon carbide, alumina and zirconia.

Wear resistance testing showed that the magnitude of wear for the OTM-906 and OTM-914 after $1 \mathrm{hr}$ testing is no more than $0,03 \%$ which is determined by high hardness and fracture toughness of the materials.

Heat resistance testing revealed the retention of practically invariant high level of hardness (94,5-96 HRC); increase in weight in $250 \mathrm{hr}$ was no more than $0,003 \mathrm{~g}$.

In the $\mathrm{Si}_{3} \mathrm{~N}_{4}-\mathrm{BN}$ system (OTM-918), the material containing $20-30 \% \mathrm{BN}$ in combination of properties meets the requirements imposed to bearing cages at most: bending strength - 200-350 MPa; HRC hardness - 20-35; wear - less than 0,02 g; elastic modulus - 90-100 GPa.

Heat resistance testing performed for $250 \mathrm{hr}$ at $700-950{ }^{\circ} \mathrm{C}$ verified the serviceability of the OTM-918 material at high temperatures and revealed insignificant weight change in the course of heating. The hardness also remains constant over all temperature range $(20 \% \mathrm{BN}-85-83 \mathrm{HRC} ; 30 \% \mathrm{BN}-70-71$ HRC).

The results of evaluation of antiwear characteristics (ball/ flat surface as friction pair, one-point contact) for monolithic materials showed that the magnitude of wear equal to $0,25 \mathrm{~mm}$ does not exceed the not-go limit $(0,31 \mathrm{~mm})$ for all materials being studied with M-16IHP-3 oil and for OTM-906 - with $\mathrm{M}-8 \mathrm{~V}_{2} \mathrm{~S}$ oil. With B-3V oil, the level of antiwear characteristics is higher as compared to steel (Fig. 1a). The antiseizure characteristics values (roll/flat surface as friction pair, onepoint contact) exceeding the not-go limit (no less than $600 \mathrm{~N}$ ) were obtained with M-16IHP and M-8V S oils (Fig. 1b).

Friction coefficient values are less than 0,15 and do not exceed the similar parameters for steel samples. Under these testing conditions, the value of friction coefficient remains less than 0,125 independent of loads, sliding speed and kind of lubricants.
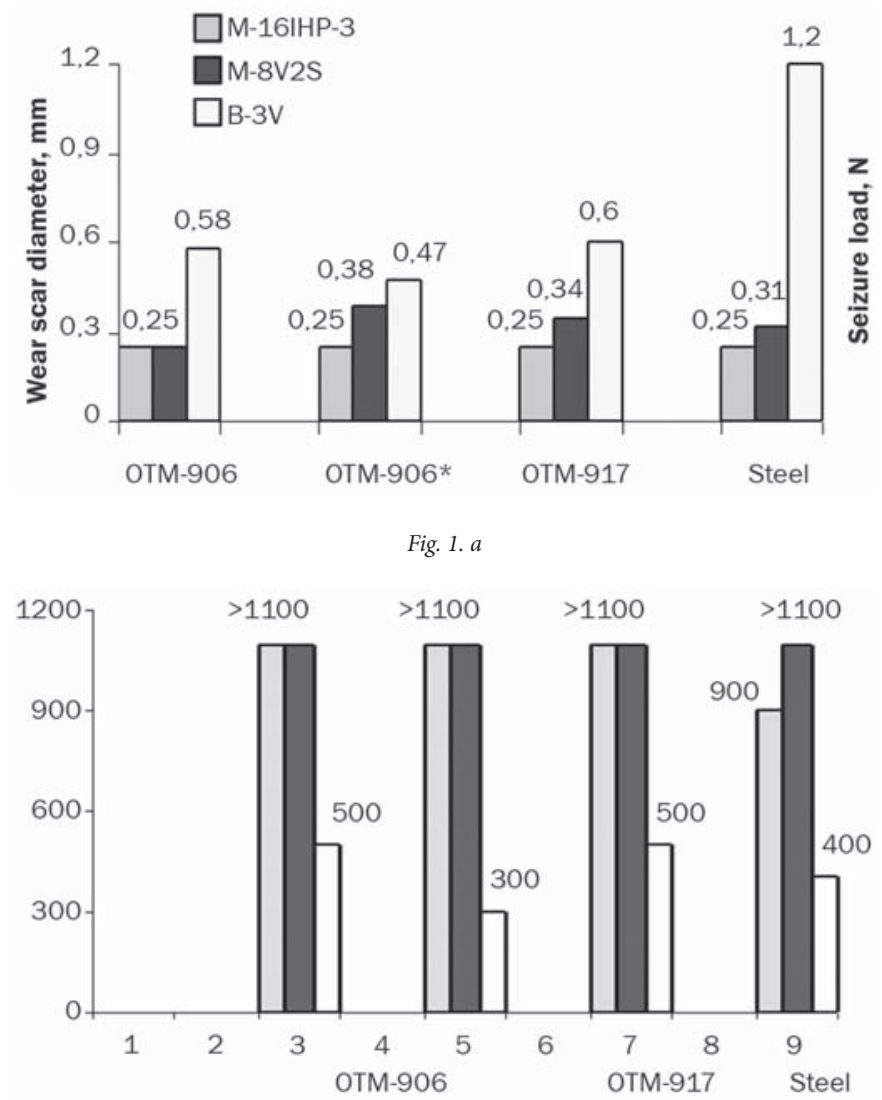

Fig. 1. $b$

Fig. 1. The results of bench testing on (a) antiwear and (b) antiseizure characteristics determined for test samples from ceramic materials and steel (with the use of standard oils). (OTM-906*-granular powder as a starting material)

1. ábra Kerámia minták és acél kopás- (a) és beragadás-(b) csökkenési jellemzőinek próbapados vizsgálati eredményei szabványos olajok felhasználása esetén. (Kiindulási anyag: OTM-906* szemcsézett por) 
In Table 2 are given the comparison properties of the hotpressed ceramics developed at ORPE «Technologiya» and some typical foreign materials based on silicon nitride and steel used for the production of bearings [2-6].

\subsection{Ceramic bearings}

The ceramic bearing, rolling elements and bearing cages of different standard sizes (Fig. 2.) were produced from the materials developed at ORPE «Technologiya».

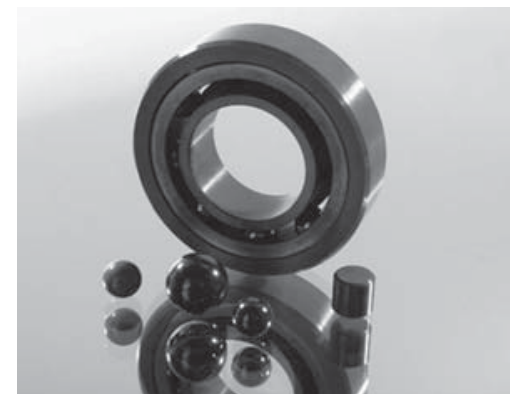

Fig. 2. $a$

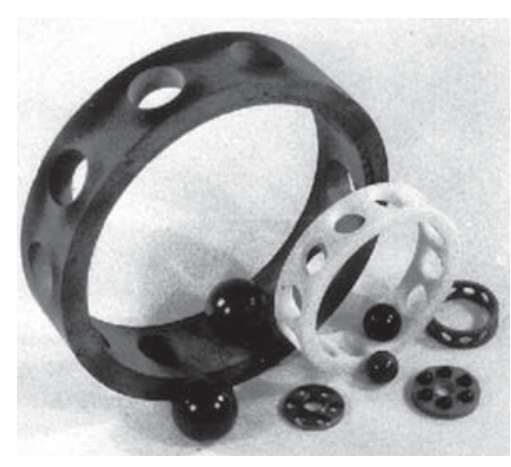

Fig. 2. $b$

Fig. 2. (a) ceramic bearing, rolling elements and (b) rolling cages of different standard sizes from hot-pressed materials

2. ábra (a) kerámia csapágy gördülö elemei, (b) magas hömérsékletü préseléssel készitett, különféle méretü, szabványos csapágykosarak

Testing of all-ceramic and hybrid bearings were carried out at the enterprises «Scientific-Production Association «Motor»,
Joint Stock Company «Scientific-Production Association «Saturn» and Federal State Unitary Enterprise «CIAM» named after P. I. Baranov. Various conditions with gradual increase of rotation frequency from 3000 to $72000 \mathrm{rpm}$, axial and radial loads, with the use of air-oil cooling system and lubrication with oil fog were applied.

Under the axial load of $1000 \mathrm{~N}$ and gradual increase of rotation frequency from 3000 to $15000 \mathrm{rpm}$ the ceramic bearing worked for $47 \mathrm{~min}$ without lubrication. The inspection of bearing assembly after disassembling revealed a substantial wear of the bearing cage made from bronze with hardness $\mathrm{HRC}<20$ (Fig. 3. a).

In the testing of the ceramic bearing under increased vibration load at a frequency of 20 000-40 $000 \mathrm{rpm}$ operating time measured $16 \mathrm{~min}$. Visual inspection revealed the fragmental failure of the bearing along the outer race (Fig. 3. b) caused by vibration overload. Damage on the inner race, rolling elements and bearing cage was not observed.

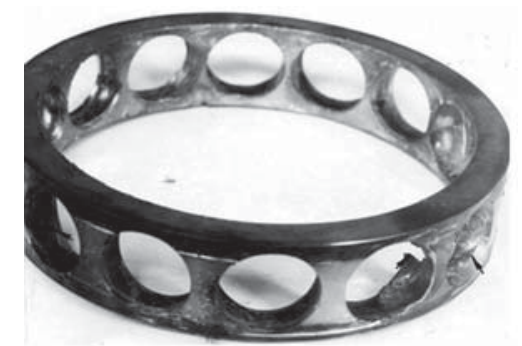

Fig. 3. a

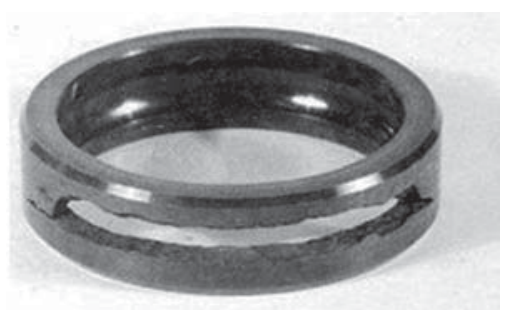

Fig. 3. $b$

Fig. 3. (a) fracture mode for the bronze bearing cage and (b) the outer race after bearing testing

3. ábra (a) bronz csapágykosár törésképe, (b) külső csapágy-gyürü a tesztelés után

\begin{tabular}{|c|c|c|c|c|c|c|c|}
\hline & $\begin{array}{l}\text { NC-132 [2] } \\
\text { Norton }\end{array}$ & $\begin{array}{c}\text { NBD-200 } \\
{[3,4]} \\
\text { Norton }\end{array}$ & $\begin{array}{l}\text { SN-101C } \\
{[3,4]} \\
\text { Saint- } \\
\text { Gobain }\end{array}$ & $\begin{array}{c}\text { Ceralloy } \\
\text { 147-31N [5] } \\
\text { Ceradyne }\end{array}$ & $\begin{array}{c}\text { OTM-906, } \\
\text { OTM-914 } \\
\text { ORPE } \\
\text { "Technologiya" }\end{array}$ & $\begin{array}{l}\text { OTM-917 } \\
\text { ORPE } \\
\text { "Techno- } \\
\text { logiya" }\end{array}$ & $\begin{array}{c}\text { Bearing } \\
\text { steel } \\
{[6]}\end{array}$ \\
\hline Density, $\mathrm{g} / \mathrm{cm}^{3}$ & 3,20 & 3,16 & 3,21 & 3,21 & $3,30-3,450$ & $3,17-3,24$ & $7,60-7,85$ \\
\hline Hardness, HRC & 80,00 & 80,00 & $>78,00$ & - & $94,00-96,00$ & $92,00-94,00$ & 64,00 \\
\hline $\begin{array}{l}\text { Ultimate bending strength, } \\
\mathrm{MPa}\end{array}$ & 700,00 & $>900,00$ & $>1000,00$ & 800,00 & $700,00-830,00$ & 690,00 & 800,00 \\
\hline Modulus of elasticity, GPa & 330,00 & 320,00 & 310,00 & 310,00 & 280,00 & 260,00 & 190,00 \\
\hline Fracture toughness, $\mathrm{MPa} \cdot \mathrm{m}^{1 / 2}$ & $5,00-6,00$ & $>5,50$ & $>6,50$ & 5,80 & $7,00-9,00$ & $5,50-6,50$ & 25,00 \\
\hline \multicolumn{8}{|c|}{ Thermal expansion coefficient, $10^{-7} \mathrm{~K}^{-1}$ in the temperature range, } \\
\hline $20-100^{\circ} \mathrm{C}$ & 3,20 & - & - & 3,10 & - & - & 12,30 \\
\hline $20-1000^{\circ} \mathrm{C}$ & - & 2,90 & 3,70 & - & 3,80 & 3,50 & - \\
\hline Thermal conductivity $\mathrm{W} / \mathrm{m} \cdot \mathrm{K}$ & - & 29,00 & 34,00 & - & 16,00 & - & $40,00-50,00$ \\
\hline Operating temperature, ${ }^{\circ} \mathrm{C}$ & 1100,00 & 1000,00 & 1000,00 & - & $1300,00-1500,00$ & 1300,00 & 320,00 \\
\hline
\end{tabular}

Table 2. Comparison properties of the ceramic materials based on silicon nitride and steel

2. táblázat Szilícium-nitrid alapú kerámiák és acél tulajdonságainak összehasonlítása 
An investigation of serviceability of small-sized radial-thrust ceramic (of type 36206) and hybrid (of type 126206) bearings was performed at CIAM on a test bench under the conditions approaching the operating conditions for rotary-table bearings in small-sized gas turbine engines [7]. The ceramic bearings were tested at high rotation frequency (45 000-65 $000 \mathrm{rpm}$ ) under axial and radial loading equal to 2000 and $200 \mathrm{~N}$ respectively. Entire life (test duration) for the bearing measured $10 \mathrm{hr} 15 \mathrm{~min}$. The inspection revealed a satisfactory state of the balls and race ways.

The testing verified the hybrid bearing serviceability at high speed parameter equal to $d_{m} \times n=3,5 \times 10^{6} \mathrm{~mm} \times \mathrm{rpm}$, where $\mathrm{d}_{\mathrm{m}}$ is the diameter between rolling elements centers in $\mathrm{mm} ; \mathrm{n}-$ the rotation frequency in rpm. Axial load measured 2000-2500 $\mathrm{N}$ and radial load 350-500 N. Duration of testing under oil fog and oil deficiency conditions at rotation frequency equal to 65 $000 \mathrm{rpm}$ measured $8 \mathrm{hr}$.

\subsection{Ceramic balls}

Comparison testing of the bearings of 36203E type with ceramic (OTM-917 and $\mathrm{Si}_{3} \mathrm{~N}_{4}$ from SKF [8]) and metal balls on high-frequency electric spindle was performed at VNIPP. Duration of testing of ceramic balls at a rotation frequency equal to 36 000-63 $000 \mathrm{rpm}$ measured $\sim 200 \mathrm{hr}$. Maximum rotation speed of electric spindle with metal balls measured $55000 \mathrm{rpm}$.

At a rotation frequency of $42000 \mathrm{rpm}$ the bearing with metal balls showed $8-10 \%$ less vibration than both of hybrid bearings with the balls manufactured at ORPE «Technologiya» and SKF. However, at a rotation frequency of $36000 \mathrm{rpm}$ the vibration and temperature levels of hybrid bearing are considerably lower than that of the metal one (Table 3.).

\begin{tabular}{|c|c|c|c|c|}
\hline $\begin{array}{l}\text { Endurance } \\
\text { hours }\end{array}$ & $\begin{array}{l}\text { Rotation fre- } \\
\text { quency [rpm] }\end{array}$ & $\begin{array}{c}\text { Spindle } \\
\text { vibration } \\
{[\mathrm{mm} / \mathrm{s}]}\end{array}$ & $\begin{array}{c}\text { Rundown } \\
\text { [s] }\end{array}$ & $\begin{array}{c}\text { Shaft } \\
\text { temperature } \\
{\left[{ }^{\circ} \mathrm{C}\right]}\end{array}$ \\
\hline \multicolumn{5}{|c|}{ With metal balls } \\
\hline \multirow[t]{2}{*}{150} & $36000-55000$ & $0,70-1,20$ & $46-72$ & $37-49$ \\
\hline & With ceramic ba & s (OTM-917) & & \\
\hline \multirow[t]{2}{*}{154} & $36000-63000$ & $0,90-1,10$ & $48-76$ & $32-45$ \\
\hline & With ceramic & alls (SKF) & & \\
\hline 449 & $36000-63000$ & $0,72-0,90$ & $51-83$ & $40-47$ \\
\hline 3. táblázat & $\begin{array}{l}\text { ts of comparison tes } \\
\text { l balls on high-frequ } \\
\text { gyfrekvenciás elektr }\end{array}$ & $\begin{array}{l}\text { g of the bearing } \\
\text { cy electric spind } \\
\text { os orsón lévö, } 3\end{array}$ & $\begin{array}{l}\text { sof } 36203 \\
\text { lle } \\
6203 \text { E tipu }\end{array}$ & $\begin{array}{l}\text { vith ceramic and } \\
\text { imia-, illetve }\end{array}$ \\
\hline & lyókkal szerelt cs & yak összeha & litó vizsgál & eredményei \\
\hline
\end{tabular}

\subsection{Ceramic bearing cage}

Bearing cages of diameter 20-160 mm were manufactured from OTM-918 (20\% BN) and tested in hybrid bearings. Bench testing of the bearing cage in the metal bearing of 206 type verified the serviceability in operation with lubrication. In this testing, the rotation frequency measured $36000 \mathrm{rpm}$, axial and radial loads -2500 and $500 \mathrm{~N}$ respectively, duration of testing measured $14 \mathrm{hr} 30 \mathrm{~min}$. In the examination of the balls, the points of contact with the outer race were detected on the external face, which is indicative of design deficiency.

\section{Conclusion}

The investigations performed showed high tribological characteristics of the OTM-grade materials meeting the requirements for bearing ceramics. Amongst them, OTM906 has the highest back-to-back endurance values owing to structural homogeneity of this ceramics.

OTM-918 of composition $\mathrm{Si}_{3} \mathrm{~N}_{4}-\mathrm{BN}$ offers high heat resistance, corrosion resistance to molten metals and excellent machinability with relatively high strength and in consequence holds promise for development of ceramic bearing cages.

The advisability of the development of ceramic bearings for relatively low-loaded rotor and stator components of small size as well as rolling elements of hybrid bearings has been confirmed. The testing of hybrid bearings with balls from hot-pressed materials showed good results in vibration and temperature level, which makes it possible to use them in highfrequency electric spindles.

\section{References}

[1] Ershova, N.I. - Kelina, I.Yu - Pavlova, Z.V.: Structures from composite materials 1993, № 4, p.36-39.

[2] Website. www.norton.com.

[3] Cerbec ceramic bearing balls materials. - website. www.cerbec.com.

[4] Hannoosh, J. G.: Des. News 1988, 44, № 22, p. 224-225, 228-233.

[5] Ceradyne, Inc. prospectus. - website. www.ceradyne.com.

[6] The rules of Bearing Design prospectus. - website. www.cerbec.com.

[7] Nozhnitsky, Yu.A. - Fedina, Yu.A. - Rekin, A.D. - Petrov, N.I.: New production methods and GTE reliability, scientific and technical collection: Composite and ceramic materials in GTE, M., 2003, Issue 3, p. 56-82.

[8] Hultman, A. - Veimark, A.K.: EVOLUTION, № 4, 1998, p. 25-27.

\section{Szilicium-nitrid alapú, magas hőmérsékleten is kopásálló anyagok}

A gördülốcsapágyak olyan, rendkívül nagy igényeket támasztó szerelvények, amelyek sok vonatkozásban meghatározzák az űrhajózási, a kôolaj- és gázszállítási berendezéseknek, a nagy teljesítményú turbináknak, az elektromos erômúvek és atomerômúvek turbináinak, a szárazföldi és vízi szállítás berendezéseinek, a szivattyútelepeknek a múködését. A szilícium-nitrid alapú kerámiák nagy keménységūek és kopásállóságúak, ugyanakkor a fémekhez képest jóval kisebb sưrūségũek, ami lehetôvé teszi, hogy belôlük hosszú élettartamú, magas hômérsékleten és nagy fordulatszámon (több mint 100.000/perc) múködô, ugyanakkor korrózióálló, kis zajszintû és nagy beállítási pontosságú alkatrészeket készítsenek. A magas hômérsékletû formázással kialakított szilícium-nitrid anyagok a többi kerámiákhoz képest maximális szilárdsággal rendelkeznek, és ez az, amiért különösen ígéretes a gördülōcsapágyakhoz történố felhasználásuk. A szilícium-nitrid alapú kerámiák széles választékát fejlesztettük ki. A magas hômérsékletû formázással elôállított OTM906 és OTM-914 jelû anyagok mind összetételükben, mind szerkezeti felépítésükben és tulajdonságaikban megfelelnek a világon a legjobbnak tartott, NC-101C és NBD-200 osztályú csapágykerámiáknak. Kidolgoztunk egy a $\mathrm{Si}_{3} \mathrm{~N}_{4}-\mathrm{BN}$ rendszerbe tartozó kompozit anyagot is. Mivel a szilícium-nitrid és a finom, önkenố tulajdonságú bór-nitrid nem lép egymással kémiai reakcióba, lehetôség nyílik olyan csapágyrögzítô gyưrūk kialakítására, amelyek a szelektív bór-nitrid eloszlás eredményeképpen megnövelt önkenô képességgel rendelkeznek. Bemutatjuk a kifejlesztett anyagok tribológiai tulajdonságaival kapcsolatos kutatásainknak, valamint a kerámia gördülő́csapágyak tesztelésének eredményeit.

Kulcsszavak: szilícium-nitrid, bór-nitrid, magas hômérsékletû formázás, gördülốcsapágy, csapágykosár, kopásállóság, surlódásvizsgálat 